DOI: $10.51480 / 1899-5101.13 .3(27) .3$

\title{
Polish and Ukrainian University Students' Perspectives on Academic Writing: A Comparative Overview
}

\author{
Mariya Kozolup \\ (iD) ORCID: 0000-0002-5892-6696 \\ IVAN FRANKO NATIONAL UNIVERSITY OF LVIV, UKRAINE
}

\section{Mariya Kokor}

(iD) ORCID: 0000-0002-7658-356X

IVAN FRANKO NATIONAL UNIVERSITY OF LVIV, UKRAINE

\author{
Ruslan Savchynskyi \\ (iD) ORCID: 0000-0002-0678-1755 \\ IVAN FRANKO NATIONAL UNIVERSITY OF LVIV, UKRAINE
}

\begin{abstract}
Communication, both written and oral, as the key to academic and professional success has received much scholarly attention in the academic communities of Western Europe and North America. However, in the Eastern European educational scene, teaching academic communication, especially academic writing, in institutions of higher education has been largely neglected for a long time. This research attempts to look at academic writing practices at two universities in Ukraine and Poland from the students' perspectives. The survey conducted among students pursuing master's degrees in education and pedagogy at both universities aimed to reveal their attitudes, beliefs and opinions in three domains: cognitive, social and affective. The results lead to some important inferences: students' exposure to academic writing is insufficient; the potential of writing as a learning tool is not fully understood; students' awareness of academic integrity is rather low. The tendencies observed across institutions are mostly similar with occasional significant differences.
\end{abstract}

KEYWORDS: academic writing, academic socialization, cognitive development, affective factors, writing instruction. 


\section{INTRODUCTION}

In order to succeed in the ever-changing multi-perspective global career marketplace, college and university graduates need to be equipped with flexible life-long skills, of which communication skills are paramount. Indeed Duff (2017) argues,

people must learn new ways of speaking, writing, interpreting, and representing meaning through expanding repertoires of semiotic and communication tools, for new purposes and audiences, and with new networks of colleagues ... [since] their work may cross communities, disciplines, professions, languages, cultures, and geographical boundaries, requiring the expansion of their communication repertoires (Duff 2017, 255-256).

The understanding of complex social and cultural processes in educational and workplace environments will help us better determine student needs and set our teaching goals to face new challenges including the increasing demands for improved academic writing in higher education.

So far, few researchers have attempted to explore the diverse scene of academic literacy development patterns at institutions of higher education across Europe. Kruse et al. (2016) suggest it is nearly impossible to comprehend European writing practices, inasmuch as every nation follows its own instructional and assessment procedures that stem from their educational traditions. However, recent shifts towards inter-university cooperation with the ultimate goal of creating a common European education area of shared degree programs, a unified credit transfer system, qualification frameworks, and accreditation programs require further investigation of academic communication cultures of all Europe's nations.

In order to develop the most effective models of teaching academic writing in institutions of higher education, it is important to hear the voices of every stakeholder: community members, prospective employers, disciplinary faculty, language teachers and the students. Cook-Sather et al. (2014) emphasize the benefits of bringing students' insights into a meaningful dialogue with the faculty about teaching and learning processes, employing the principles of respect, reciprocity and shared responsibility. Hegbloom et al. (2017) support this view and insist on the importance of listening to student voices while developing writing pedagogies. In this research, we attempt to look at academic writing practices in two Eastern European universities: Ivan Franko National University of Lviv, Ukraine (LNU) and University of Warsaw, Poland (UW) from students' perspectives. 


\section{LITERATURE REVIEW}

\section{THE CONCEPT OF ACADEMIC WRITING}

The notion of academic writing is generally applied to writing used for educational purposes, especially at university level, and for scholarly publications. Coffin et al. (2003) contend academic writing is central to teaching and learning in higher education and functions as a tool with three key purposes. It is used for: (i) student assessment of both their disciplinary knowledge and language skills; (ii) learning by contributing to more effective knowledge acquisition and facilitating the ability to think critically, and (iii) disciplinary community socialization by exposing students to disciplinary specific genres and language norms.

Academic writing is closely linked with academic literacy; the latter combines reading, writing and other forms of communication and encompasses an array of skills and practices that "bring students into intellectual engagement with knowledge, thought, and the work of professions" (Bazerman et al., 2005, p. 8). Academic writing takes place in a variety of contexts and forms ranging from a five-paragraph-general-topic essay written as a part of a foreign language course or a first-year college writing course to a term paper or a master's thesis deeply rooted in the disciplinary discourse of a student's field of concentration. Among many existing approaches to teaching academic writing in both vernacular and foreign languages, a process approach remains one of the most widely used. It regards academic writing as a non-linear, iterative process that consists of several stages such as prewriting, planning, drafting, reviewing, revising, and editing and employs a number of techniques, e.g. note-taking, journaling, mind-mapping, outlining, proofreading, editing, etc. (Curry et al., 2003).

Substantial contribution to the field of teaching academic writing across the curriculum and in the disciplines has been made by North American and Western European researchers and educators. Although previously neglected, academic writing is increasingly gaining the attention of both academia and society in Eastern Europe. Recently, scholarship on European writing cultures has been expanded through a collection of country reports describing and analyzing writing practices, genres and languages used within higher education systems of 15 European nations including Bulgaria, Poland, Romania and Ukraine (Kruse et al., 2016). Another joint research project - the LIDHUM (Literacy Development in the Humanities) project launched in 2011 in Ukraine, Poland, Romania, and Macedonia - addressed university student writing in Central and Eastern Europe in the context of dynamic changes currently taking place in the region. This intercultural study revealed similar challenges faced by the higher education systems of these countries in implementing new models of teaching 
academic writing that stem from common cultural and historical backgrounds (Chitez et al., 2018).

\section{ACADEMIC WRITING AND COGNITIVE DEVELOPMENT}

Theories about the cognitive function of academic writing rest upon the idea of the existing correlation between language and learning, which goes back to Lev Vygotsky and James Britton. Both scholars emphasize the developmental role of language. Vygotsky (2005) maintains that language serves as a tool for organizing child behavior, a means of social contact with other people, and at the same time an instrument of auto stimulation, eventually leading to the transition of an individual onto a higher behavioral level. Britton (1993) regards language as a mechanism of experience representation, through which individuals construct their own picture of the world. More specific research projects undertaken to establish direct links between writing, critical thinking, and ultimately, the overall academic progress of learners were grounded in the idea that writing creates a favorable context for in-depth thinking about a certain learning content, eventually facilitating the development of cognitive skills (Langer \& Applebee, 1987). Thus, a number of studies have discussed the ways in which writing enhances students' usage of learning strategies in a variety of educational settings (Allan \& Driscoll, 2014), established links between academic writing, critical thinking and general academic literacy (Borglin, 2012), or suggested techniques through which academic writing courses can promote the development of students' thinking skills in an active way (Klimova, 2013).

\section{ACADEMIC DISCOURSE SOCIALIZATION}

The role of oral and written communication in educational environments as a means of internalizing into academic communities has been discussed within the scope of broader studies dedicated to language socialization. Ochs \& Schieffelin, 2017 regard the latter as being a twofold process of socialization through and into language. A great deal of scholarly research has focused on studying complex social and cultural processes of socialization into academic and disciplinary discourse communities through writing and composition, as well as oral interactive practices such as group discussions, classroom negotiations, academic presentations, etc. (Kobayashi et al., 2017). Bazerman et al. (2005) define academic language socialization as a process through which "individuals learn to enter into the discussions and gain access to the resources of academic disciplines through learning specialized language use and participating in academic activity settings" (p. 8). Mastering the appropriate genres of communication thereby becomes an essential prerequisite for gaining the respective disciplinary community membership. 
As they move further towards disciplinary communities, students may need stronger support from the insiders of these communities (i.e. disciplinary faculty) not only in gaining subject-specific knowledge and skills, but also in understanding specific language conventions. Thus, there has been an ongoing debate about sharing the responsibility for quality writing instruction between disciplinary faculty and language departments. Opinions differ on whether language and writing should be taught in general courses with no commitment to any specific subject content, or within the disciplines to emphasize their specific discourse conventions. The proponents of the "generalistic" approach assume that generic communicative skills do not differ much across academic fields and therefore language courses need to concentrate on common language forms and transferable skills (Hyland, 2006). The opposing view, however, maintains that writing processes and conventions vary considerably across disciplines since writing is a "complex, context-specific, rhetorically situated and socially-rooted" activity (Rankins-Robertson et. al., 2010, p. 57). That being said, it should be noted, that applying a discipline-specific approach to teaching academic writing is a challenging pedagogical task due to institutional limitations in organization and human resources as well as specific and often contradictory demands for writing set forward by disciplinary departments (Flowerdew \& Costley, 2016).

\section{AFFECTIVE FACTORS IN ACADEMIC WRTITING}

Multiple studies have addressed affective factors in learning. McLeod (1991) refers to the "affective phenomena" that include feelings, emotions, moods, attitudes, anxieties, beliefs, values and motivation, all of which have an impact on student writing processes and products. Building on previous studies, Petric (2002) and MacArthur et al. (2015) claim the existence of intricate connections between students' beliefs about writing, writing-related experiences, motivation and progress in academic writing. Meanwhile Hegbloom et al. (2017) point out that students who acknowledge their positive feelings about writing also admit having a higher degree of engagement in the process as well as a stronger disposition to succeed with their work.

Students' perceptions of self-efficacy play an essential role in their development as writers. Perceived self-efficacy, Bandura (1997) suggests, concerns individual beliefs about one's ability to perform various tasks under different circumstances. A number of studies have discussed the correlation between student's self-efficacy beliefs about their ability to deal with academic reading and writing tasks and their actual writing performance (Pajares \& Johnson, 1994; Tanyer, 2015).

The way students' writing is evaluated and assessed can be crucial in forming their opinions about academic writing in general and hence their success as writers. Some researchers expressed a negative attitude to grading student writing while emphasizing the importance of teachers' feedback and peer reviewing (Holaday, 
1997; Wood \& Kurzel, 2008). The positive effects of the latter include better acquisition of new knowledge, improvement in student cooperation, development of the feeling of audience and enhancement of writing ownership in learners, as well as the overall advance in the quality of student writing (Anastasiadou \& Aristotelous, 2015). Studies of learners' attitudes to peer feedback conducted in various cultural and academic settings revealed a general tendency towards positive evaluation of peer feedback along with the acknowledgement of its usefulness, although, certain skeptical attitudes about the value of peer review were observed in some teacher-centered cultures (Ilkos, 2018).

Recent research, conducted at the University of Łódź (Poland), explored students' opinions on various forms of teachers' feedback, peer reviews and journal writing in first year writing courses. The study revealed a general approval of these writing instruction techniques, particularly an individual conversation with a teacher and journal writing (Majchrzak \& Salski, 2018). However, no surveys or other empirical studies with the aim of eliciting information on university students' attitudes to academic writing instruction either in their first or foreign languages have been carried out in Ukraine.

\section{ACADEMIC WRITING AND PLAGIARISM}

A number of researchers hold that academic discourse is largely grounded in intertextuality, which is tightly linked with multimodality and author identity (Kobayashi et al., 2017). Hence, numerous studies have approached problems of agency, authorship, authenticity, voice and plagiarism. Researchers who address the issue of plagiarism show general agreement that it should be studied in reference to specific academic environments, cultures and traditions ( $\mathrm{Gu} \&$ Brooks, 2008). One recent comparative study conducted among students and their supervisors with the aim of assessing knowledge and attitudes concerning referencing and plagiarism has revealed that responses of the students reflect their differing backgrounds. In particular, Western Europeans and North Americans showed better understanding of the nature of plagiarism than did other nationalities (Lindahl \& Grace, 2018).

Safeguarding academic integrity and related issues is a major challenge for Eastern European education systems, such as Ukraine's higher education. To affect a solution, Ukraine's Ministry of Science and Education cooperated with the American Council for International Education to launch the Strengthening Academic Integrity in Ukraine Project (SAIUP). The project focuses on boosting academic writing practices in Ukraine and forming an academic culture based on the values of trust, transparency, honesty and academic work. Two large-scale surveys on academic integrity conducted in 10 Ukrainian universities in 2016 and 2018 revealed that the most common causes of academic misconduct were boring assignments, repeated topics, absence of clear writing assessment criteria, 
insufficient feedback from professors, lack of sanctions, poorly equipped facilities, and unfavorable conditions of studying (SAIUP, 2019). Similarly, according to the 2015 report on plagiarism policies in Poland some of the reasons for plagiarism include the absence of common standards and policies of acceptable and unacceptable practices, as well as complacency and tolerance of academic dishonesty by educational institutions (Glendinning et al., 2015).

\section{SIGNIFICANCE AND PURPOSE OF THE STUDY}

Numerous studies have focused on various aspects of academic writing, especially in North America and Western Europe. However, there is a substantial gap in Eastern European scholarship on academic writing due to the cultural and historical circumstances of the development of higher education systems in these countries, including Poland and Ukraine. To date, none of the studies conducted in Polish or Ukrainian universities have addressed students' perceptions, attitudes and opinions on academic writing taking into account its cognitive, affective and social domains, and only a few studies have targeted academic integrity issues. In addition, no attempts to compare existing tendencies across the two nations have been made. The present small-scale research can contribute to filling the existing gap by gaining an insight into students' attitudes to academic writing in two universities: LNU in Ukraine and UW in Poland. The results yielded from it might be of interest to language researchers, practitioners and educators working in higher education settings, especially within the field of vernacular and foreign language academic writing instruction.

In an attempt to measure university students' attitudes towards academic writing in general, beliefs as to its role in their future professional life, awareness of plagiarism related issues, and in order to trace any differences or similarities in views of Ukrainian and Polish students, we conducted a quantitative study via a survey, which embraced a range of qualitative parameters and addressed the following research questions:

1. What are the opinions of master's students majoring in pedagogy and education about cognitive, social and affective dimensions of academic writing and its integration into university curricula?

2. Is there a significant difference in the views of Ukrainian and Polish university students on academic writing? 


\section{METHOD}

\section{INSTRUMENT}

This study is based on a survey given to master's students of education and pedagogy in two leading Ukrainian and Polish universities and employs a questionnaire as a means of collecting data. The questionnaires administered to the students included three sections. The first was designed to collect the participants' biodata of their age, gender, name of the institution where they studied, academic major and languages they used for academic writing. This section consisted of open response and selected response items.

The second section aimed to obtain information on the genres of academic writing used by the respondents in the course of their study. Students were asked to select the genres, in which they had writing experience, from a suggested list of eight items. Previous research reported the prevalence of such writing genres as a term paper and a diploma (bachelor's or master's) thesis in the higher education of both Poland and Ukraine (Majchrzak \& Salski, 2016; Yakhontova et al., 2016). In our survey, however, we concentrated on smaller genres of three groups: (1) general educational genres (a summary essay, an argumentative essay); (2) disciplinary-specific genres of writing (a lab journal, a case study, a report); (3) genres that can promote students' career progress in both education and research and can be particularly useful for master's students (a research paper, a research proposal and a personal statement / motivational letter).

The third section, designed to find out Ukrainian and Polish university students' opinions concerning their academic writing experiences, was based on a Likert scale questionnaire. This data collecting and measuring instrument is widely employed in the field of language teaching to gauge attitudes, beliefs or opinions of learners and teachers, because it is simple, versatile and reliable (Mackey $\&$ Gass, 2005). The Likert scale used for this survey was five-point whereby the participants could provide responses to every statement within the following range: $5=$ strongly agree, $4=$ agree, $3=$ undecided, $2=$ disagree, $1=$ strongly disagree. The body of the Likert scale questionnaire included 30 statements addressing students' beliefs and opinions about academic writing in three major domains: cognitive, social and affective (see Tables 2-5). Items $1-5$ of the questionnaire aimed to reveal respondents' awareness of the role of writing as a tool of cognitive development. Statements 6-10 intended to discover students' beliefs concerning the significance of academic communicative skills for their social (including career) success. Statements 11-24 mainly related to the affective dimension of academic writing practices and encompassed a range of students' reactions to writing in the learning context including emotional responses, self-efficacy judgements and perceptions, attitudes and beliefs about academic integrity 
issues. Finally, statements 25-30 were designed to detect opinions about certain aspects of teaching and assessment of academic writing and its integration into university curricula.

\section{PARTICIPANTS}

Sixty master's students of education and pedagogy in the two major state Ukrainian and Polish universities - Ivan Franko National University of L'viv, Ukraine (LNU) and The University of Warsaw, Poland (UW) were selected as a sample for the study. The number of participants was limited by the total number of master's students in this field of concentration in both institutions under study: 30 in LNU and about 50 in UW. In order to match the sample sizes, we included all respondents from LNU (30 people) and randomly selected 30 respondents from UW.

Biodata collected through the first section of the questionnaire enabled us to create demographic profiles of LNU and UW survey respondents. Thus, the average respondent from LNU was a female (100\%) aged 21.4 (with a very narrow age range from 21 to 22 ) and the average UW respondent was slightly older (24.8 years old; age ranging between 22 and 50) and predominantly female (96.7\%). All respondents had some writing experience in their native language; in addition, some of them had writing experience in English: 46.7\% of LNU students and $33.3 \%$ of UW students.

\section{PROCEDURE OF DATA COLLECTION AND DATA ANALYSIS}

The survey was conducted among UW and LNU students in 2018. The questionnaires were administered to the respondents in a pen-and-paper format and were available in English, Polish and Ukrainian. The forms were filled out in the presence of one of the researchers in case the students needed help in clarifying statements or questions in the questionnaires.

After collecting the participant's responses, we analyzed them qualitatively to find out and then compare LNU and UW students' opinions about learning academic writing. For further quantitative analysis of the data, SPSS software was used. The mean scores throughout all items of the Likert scale questionnaire were calculated for both groups of respondents, arranged logically, and presented in Tables for the convenience of interpretation, description and comparison (see Tables 2-5). In order to identify the statistical significance of the differences between the groups, we applied the Mann-Whitney $U$ test, which is a non-parametric equivalent of the t-test used for relatively small independent samples. 


\section{RESULTS}

Students' biodata obtained from the first section of the questionnaire is presented in the "Participants" section of this paper. Table 1 summarizes the information on the genres of academic writing used by the respondents from both institutions. As can be seen, most students of both LNU and UW reported having experience in writing summary and argumentative essays. More LNU students reported having written case studies and research papers than did students from UW, whereas the latter wrote more research proposals. Lab journals, reports and personal statements appear to be the least utilized genres in both universities.

Table 1. Academic Writing Genres Used by Students in LNU and UW

\begin{tabular}{l|c|c}
\hline Academic writing genres & LNU \% & UW\% \\
\hline Summary essay & 83.3 & 70 \\
\hline Argumentative essay & 83.3 & 93.3 \\
\hline Lab journal & --- & 3.3 \\
\hline Report & --- & 23.3 \\
\hline Case study & 43.3 & 26.7 \\
\hline Research paper & 36.7 & 13.3 \\
\hline Research proposal & 33.3 & 50 \\
\hline Personal statement & 3.3 & 6.7
\end{tabular}

Source: Authors

The Likert scale questionnaire in the third section is the central instrument in our survey; hence, the information obtained from it is the most significant. The first five statements addressed the students' understanding of the relation between their writing practices, learning process and eventually, academic progress. Table 2 compares the mean scores for each statement at each university. Respondents from both institutions generally agreed about the positive effect of notetaking on learning material acquisition. However, both LNU and UW students expressed uncertainty about the connection between doing writing assignments and learning academic subjects, as most of them chose the undecided option. Poor understanding of the role of reflective writing in learning was revealed through students' reactions to statement 5 , in which the majority emphasized the predominant role of memorization in education. Statement 4 is the only one in the group where statistical difference between institutions has been detected (asymp. sig. (2-tailed) $=0.002$ ). It shows that Polish students recognize the link between writing and critical thinking, while the Ukrainians are not sure about it. 
Table 2. LNU and UW students' Responses to Statements 1-5

\begin{tabular}{|c|c|c|c|c|c|}
\hline Statement & Institution & Mean & St. D. & $\begin{array}{c}\text { Mann- } \\
\text { Whitney U }\end{array}$ & $\begin{array}{l}\text { Asymp. Sig. } \\
\text { (2-tailed) }\end{array}$ \\
\hline \multirow{2}{*}{$\begin{array}{l}\text { 1. The meaning of a text becomes } \\
\text { clearer if I make notes about it }\end{array}$} & LNU & 3.87 & 0.973 & \multirow{2}{*}{366.500} & \multirow{2}{*}{.186} \\
\hline & UW & 4.17 & 0.913 & & \\
\hline \multirow{2}{*}{$\begin{array}{l}\text { 2. I have a better understanding } \\
\text { of a subject if I write a paper on it }\end{array}$} & LNU & 3.30 & 1.088 & \multirow{2}{*}{438.000} & \multirow{2}{*}{.852} \\
\hline & UW & 3.30 & 1.022 & & \\
\hline \multirow{2}{*}{$\begin{array}{l}\text { 3. Learning material in the courses where } \\
\text { we do writing assignments is processed } \\
\text { better and remembered longer }\end{array}$} & LNU & 3.33 & 1.269 & \multirow[b]{2}{*}{437.500} & \multirow[b]{2}{*}{.848} \\
\hline & UW & 3.37 & 0.890 & & \\
\hline \multirow{2}{*}{ 4. Writing improves my critical thinking } & LNU & 3.00 & 1.313 & \multirow{2}{*}{245.500} & \multirow{2}{*}{.002} \\
\hline & UW & 4.00 & 0.871 & & \\
\hline \multirow{2}{*}{$\begin{array}{l}\text { 5. Disciplinary courses should be organized } \\
\text { around memorizing the subject content } \\
\text { rather than reflecting on or writing about it }\end{array}$} & LNU & 4.00 & 0.830 & \multirow[b]{2}{*}{386.000} & \multirow[b]{2}{*}{.320} \\
\hline & UW & 3.77 & 0.971 & & \\
\hline
\end{tabular}

Source: Authors

Results yielded by the analysis of the respondents' evaluation of the role academic communication skills play in their social and career success are presented in Table 3. Students of both universities admitted that communicative skills are directly related to their social confidence. The responses to statements 8 and 9 concerning the importance of writing skills for professional and academic socialization, and their impact on employment opportunities are similar in both groups and illustrate students' uncertainty regarding the issue. This, to a certain extent, contradicts the respondents' reactions to statement 7 whereby students expressed agreement about the dependence of one's career prospects on the mastery over respective genres of communication. At the same time, students do not see a strong connection between their existing communicative skills and involvement in social academic activities.

Table 3. LNU and UW Students' Responses to Statements 6-10

\begin{tabular}{|c|c|c|c|c|c|}
\hline Statement & Institution & Mean & St. D. & $\begin{array}{c}\text { Mann- } \\
\text { Whitney U }\end{array}$ & $\begin{array}{l}\text { Asymp. Sig. } \\
\text { (2-tailed) }\end{array}$ \\
\hline \multirow{2}{*}{$\begin{array}{l}\text { 6. Ability to communicate effectively } \\
\text { boosts my social confidence }\end{array}$} & LNU & 4.50 & 0.731 & \multirow{2}{*}{399.500} & \multirow{2}{*}{.368} \\
\hline & UW & 4.60 & 0.770 & & \\
\hline \multirow{2}{*}{$\begin{array}{l}\text { 7. Mastering academic and professional } \\
\text { genres of communication is an essential } \\
\text { prerequisite for a successful career }\end{array}$} & LNU & 4.00 & 0.830 & \multirow{2}{*}{308.000} & \multirow{2}{*}{.023} \\
\hline & UW & 4.47 & 0.681 & & \\
\hline \multirow{2}{*}{$\begin{array}{l}\text { 8. University graduates with good writing } \\
\text { skills have better employment opportunities }\end{array}$} & LNU & 3.27 & 1.143 & \multirow{2}{*}{352.000} & \multirow{2}{*}{.135} \\
\hline & UW & 3.70 & 1.179 & & \\
\hline
\end{tabular}




\begin{tabular}{|c|c|c|c|c|c|}
\hline Statement & Institution & Mean & St. D. & $\begin{array}{c}\text { Mann- } \\
\text { Whitney U }\end{array}$ & $\begin{array}{c}\text { Asymp. Sig. } \\
\text { (2-tailed) }\end{array}$ \\
\hline \multirow{2}{*}{$\begin{array}{l}\text { 9. I would be engaged in more social } \\
\text { activities (science circles, student } \\
\text { organizations, etc.) at university } \\
\text { if my communication skills were better }\end{array}$} & LNU & 3.10 & 1.269 & \multirow{2}{*}{370.500} & \multirow{2}{*}{.229} \\
\hline & UW & 2.70 & 1.317 & & \\
\hline \multirow{2}{*}{$\begin{array}{l}\text { 10. A person becomes a member } \\
\text { of a professional or academic } \\
\text { community through acquisition of its } \\
\text { communication conventions (genres) }\end{array}$} & LNU & 3.47 & 0.860 & \multirow[b]{2}{*}{389.000} & \multirow[b]{2}{*}{.337} \\
\hline & UW & 3.67 & 0.844 & & \\
\hline
\end{tabular}

Source: Authors

Next comes the group of statements targeted at discovering students' emotional reactions to writing practices, self-efficacy judgements as well as assumptions about the writing process and product (see Table 4). Data analysis shows that respondents from both LNU and UW are inclined to admit that they have some apprehension towards academic writing (statements 12 and 13); they also tend to believe that writing abilities are rather natural than developed. However, the students from both institutions did not report having difficulty with such aspects of the writing process as idea generating and argument development. Regarding characteristics of academic texts, representatives of both groups expressed an assumption about the importance of meeting the standards of style, structure, format, etc. The statistically significant difference between LNU and UW students' responses to statement 17 (asymp. sig. (2-tailed) $=0.002$ ) suggests that the latter attach more importance to the content of writing, whereas the former give priority to the formal features.

Table 4. LNU and UW Students' Responses to Statements 11-24

\begin{tabular}{|c|c|c|c|c|c|}
\hline Statement & Institution & Mean & St. D. & $\begin{array}{c}\text { Mann- } \\
\text { Whitney U }\end{array}$ & $\begin{array}{l}\text { Asymp. Sig. } \\
\text { (2-tailed) }\end{array}$ \\
\hline \multirow{2}{*}{$\begin{array}{l}\text { 11. Some people have inherent aptitude } \\
\text { for writing while others do not }\end{array}$} & LNU & 3.63 & 1.129 & \multirow{2}{*}{355.000} & \multirow{2}{*}{.135} \\
\hline & UW & 4.07 & 0.944 & & \\
\hline \multirow{2}{*}{$\begin{array}{l}\text { 12. I am rather apprehensive about } \\
\text { doing writing assignments }\end{array}$} & LNU & 3.13 & 1.074 & \multirow{2}{*}{305.500} & \multirow{2}{*}{.027} \\
\hline & UW & 3.77 & 1.104 & & \\
\hline \multirow{2}{*}{$\begin{array}{l}\text { 13. I usually procrastinate with } \\
\text { my writing assignments }\end{array}$} & LNU & 3.23 & 1.223 & \multirow{2}{*}{364.500} & \multirow{2}{*}{.194} \\
\hline & UW & 3.63 & 1.217 & & \\
\hline \multirow{2}{*}{$\begin{array}{l}\text { 14. Generating ideas for a writing assignment } \\
\text { is a significant challenge for me }\end{array}$} & LNU & 3.00 & 1.017 & \multirow{2}{*}{444.000} & \multirow{2}{*}{.926} \\
\hline & UW & 2.90 & 1.094 & & \\
\hline \multirow{2}{*}{ 15. I have difficulty developing an argument } & LNU & 2.97 & 1.377 & \multirow{2}{*}{398.000} & \multirow{2}{*}{.429} \\
\hline & UW & 2.63 & 1.245 & & \\
\hline \multirow{2}{*}{$\begin{array}{l}\text { 16. Following style conventions and } \\
\text { documentation format is essential } \\
\text { for academic writing }\end{array}$} & LNU & 3.70 & 0.915 & \multirow{2}{*}{419.000} & \multirow{2}{*}{.628} \\
\hline & UW & 3.80 & 1.126 & & \\
\hline
\end{tabular}




\begin{tabular}{|c|c|c|c|c|c|}
\hline Statement & Institution & Mean & St. D. & $\begin{array}{c}\text { Mann- } \\
\text { Whitney U }\end{array}$ & $\begin{array}{l}\text { Asymp. Sig. } \\
\text { (2-tailed) }\end{array}$ \\
\hline \multirow{2}{*}{$\begin{array}{l}\text { 17. Structure and organization of a text } \\
\text { are less important than its content }\end{array}$} & LNU & 2.80 & 1.095 & \multirow{2}{*}{243.500} & \multirow{2}{*}{.002} \\
\hline & UW & 3.73 & 0.868 & & \\
\hline \multirow{2}{*}{$\begin{array}{l}\text { 18. I find writing "mechanics" (e.g. grammar, } \\
\text { spelling, punctuation) boring and unimportant }\end{array}$} & LNU & 2.17 & 1.234 & \multirow{2}{*}{412.000} & \multirow{2}{*}{.550} \\
\hline & UW & 1.90 & 0.885 & & \\
\hline \multirow{2}{*}{$\begin{array}{l}\text { 19. Students can make use of the works } \\
\text { of others to support their own arguments }\end{array}$} & LNU & 3.90 & 0.885 & \multirow{2}{*}{395.500} & \multirow{2}{*}{.399} \\
\hline & UW & 3.70 & 0.988 & & \\
\hline \multirow{2}{*}{$\begin{array}{l}\text { 20. I believe I can insert a verbatim } \\
\text { copy of a fragment of another text into } \\
\text { my paper without quotation marks } \\
\text { if I mention the original author's name }\end{array}$} & LNU & 3.30 & 1.317 & \multirow[b]{2}{*}{171.500} & \multirow[b]{2}{*}{.000} \\
\hline & UW & 1.73 & 1.112 & & \\
\hline \multirow{2}{*}{$\begin{array}{l}\text { 21. It is not a problem if I unintentionally } \\
\text { fail to clearly differentiate between } \\
\text { my words and ideas and the words and } \\
\text { ideas that I get from other sources }\end{array}$} & LNU & 2.93 & 1.285 & \multirow{2}{*}{297.000} & \multirow{2}{*}{.020} \\
\hline & UW & 2.17 & 1.262 & & \\
\hline \multirow{2}{*}{ 22. I know what to do to avoid plagiarism } & LNU & 3.60 & 0.932 & \multirow{2}{*}{226.000} & \multirow{2}{*}{.000} \\
\hline & UW & 4.40 & 0.770 & & \\
\hline \multirow{2}{*}{$\begin{array}{l}\text { 23. I am competent in academic } \\
\text { writing in my first language }\end{array}$} & LNU & 3.67 & 0.758 & \multirow{2}{*}{412.000} & \multirow{2}{*}{.546} \\
\hline & UW & 3.80 & 0.887 & & \\
\hline \multirow{2}{*}{$\begin{array}{l}\text { 24. I am competent in academic } \\
\text { writing in a foreign language }\end{array}$} & LNU & 2.87 & 1.106 & \multirow{2}{*}{323.500} & \multirow{2}{*}{.051} \\
\hline & UW & 2.30 & 1.119 & & \\
\hline
\end{tabular}

Source: Authors

We were particularly interested to see and compare Polish and Ukrainian students' understanding of the nature of plagiarism. Analysis of responses to the statements devoted to this issue reveals statistically significant differences across groups (for statement 20 - asymp. sig. (2-tailed) $=0.000$; for statement $21-$ asymp. sig. $(2$-tailed $)=0.020)$, from which we can assume that respondents from UW are more knowledgeable of the problem, although their choices may imply a certain confusion in determining cases of plagiarism. By contrast, respondents from LNU demonstrated ignorance of the basic principles of academic integrity, since the majority misinterpreted examples of plagiarism as acceptable ways of academic behavior. LNU students' insufficient knowledge about plagiarism and how to avoid it, in comparison with respondents from UW, was revealed through the statistically significant difference in their responses to statement 22 (asymp. sig. $(2$-tailed $)=0.000)$. While Polish students claimed a high degree of confidence in dealing with issues of plagiarism, many Ukrainian students chose the undecided option. Respondents from both groups reported a low level of competence in academic writing in a foreign language. However, they gave a higher assessment of their writing skills in their first language.

The final group of statements concerned students' views on teaching, reviewing and assessing academic writing. Table 5 displays results for this group. From the 
responses obtained, we can infer that representatives of both institutions strongly value teacher and institutional support and obviously require more instruction in writing. The students of both universities gave preference to teacher feedback over peer feedback. The majority of the respondents expressed uncertainty about the usefulness of having their works peer reviewed before submitting them to the teacher. Apparently, the respondents were confused to a certain extent by the statement concerning the problem of sharing responsibility for writing instruction between faculty-in-the-disciplines and language instructors. This can possibly result from the lack of writing instruction in the disciplines.

Table 5. LNU and UW Students' Responses to Statements 25-30

\begin{tabular}{|c|c|c|c|c|c|}
\hline Statement & Institution & Mean & St. D. & $\begin{array}{c}\text { Mann- } \\
\text { Whitney U }\end{array}$ & $\begin{array}{l}\text { Asymp. Sig. } \\
\text { (2-tailed) }\end{array}$ \\
\hline \multirow{2}{*}{$\begin{array}{l}\text { 25. I find writing easier if a teacher } \\
\text { clearly explains the requirements and } \\
\text { assessment criteria in advance }\end{array}$} & LNU & 4.47 & 0.629 & \multirow{2}{*}{381.000} & \multirow{2}{*}{.231} \\
\hline & UW & 4.57 & 0.817 & & \\
\hline \multirow{2}{*}{$\begin{array}{l}\text { 26. The quality of my work (text) will } \\
\text { be better if I ask someone to review } \\
\text { it before the final submission }\end{array}$} & LNU & 3.30 & 1.022 & \multirow{2}{*}{445.500} & \multirow{2}{*}{.945} \\
\hline & UW & 3.30 & 1.086 & & \\
\hline \multirow{2}{*}{$\begin{array}{l}\text { 27. The course instructor (professor) should } \\
\text { take full responsibility for reviewing and } \\
\text { assessment of students' writing assignments }\end{array}$} & LNU & 3.93 & 0.868 & \multirow{2}{*}{408.000} & \multirow{2}{*}{.511} \\
\hline & UW & 3.83 & 0.834 & & \\
\hline \multirow{2}{*}{$\begin{array}{l}\text { 28. The responsibility for reviewing and } \\
\text { assessment of students' writing assignments } \\
\text { should be shared between disciplinary } \\
\text { faculty and writing instructors (consultants) }\end{array}$} & LNU & 3.00 & 1.313 & \multirow[b]{2}{*}{375.000} & \multirow[b]{2}{*}{.244} \\
\hline & UW & 3.40 & 0.724 & & \\
\hline \multirow{2}{*}{$\begin{array}{l}\text { 29. I think students should receive } \\
\text { more instruction on genres and } \\
\text { processes of academic writing }\end{array}$} & LNU & 3.80 & 0.887 & \multirow{2}{*}{439.500} & \multirow{2}{*}{.869} \\
\hline & UW & 3.73 & 1.015 & & \\
\hline \multirow{2}{*}{$\begin{array}{l}\text { 30. It would be good to have access } \\
\text { to academic resources (e.g. a writing } \\
\text { center) to consult me on various } \\
\text { aspects of writing at university }\end{array}$} & LNU & 4.07 & 1.081 & \multirow[b]{2}{*}{345.500} & \multirow[b]{2}{*}{.088} \\
\hline & UW & 4.50 & 0.777 & & \\
\hline
\end{tabular}

Source: Authors

\section{DISCUSSION}

While planning this research we intended to examine LNU and UW students' attitudes towards the cognitive, social and affective aspects of writing, and trace differences in perception of academic writing by students of both universities. The results demonstrated similar perceptions overall by both groups, as well as revealed certain tendencies, which pose a few questions for discussion.

One of the tendencies observed from the respondents' answers is the insufficient exposure to academic writing, and discipline-specific writing in particular, 
during their years of studying in both universities. Most of Polish and Ukrainian respondents expressed their need to receive more instruction on academic writing and acknowledged the importance of writing consultancy services (such as writing centers). This is consistent with Majchrzak and Salski (2016) who report that Polish students do not write much apart from foreign language courses and "regret the lack of written assignments" (pp. 152-153). Similarly, Yakhontova et al. (2016) point out that academic writing is generally not included in Ukrainian university curricula either in the vernacular or foreign languages.

Another tendency concerns the cognitive domain of writing. Even though a vast corpus of scholarship has exposed writing as a learning tool with a significant potential to encourage active thinking and learning (Allan \& Driscoll, 2014; Borglin, 2012; Klimova, 2013), the participants in our survey could not recognize the interconnection between critical thinking and academic writing. The explanation might lie in the nature and the purpose of the writing assignments that Ukrainian and Polish students encounter. Majchrzak and Salski (2016) argue that due to the product approach that dominates academic writing in Polish higher education, writing tasks hardly ever require creative or critical thinking; instead, they are designed to assess students' subject knowledge and ability to use sources.

Students' responses to the group of statements addressing the correlation between their communicative skills and social confidence have demonstrated some discrepancy. While the majority of respondents strongly agreed with statements 6 and 7, the students of both institutions expressed uncertainty about the usefulness of academic writing skills and knowledge of genre conventions for joining academic and professional communities. This situation might be the result of the students' little experience with disciplinary-specific genres. As our study has revealed, students of both universities are quite familiar with such general educational genres as summary and argumentative essays, whereas a much smaller percentage of the respondents reported using disciplinary genres (e.g. reports or case studies). This finding is supported by Yakhontova et al. (2016) who note that a summary essay is the most common genre of university writing in Ukraine after a diploma paper.

Of interest to us were LNU and UW students' ideas about some aspects of academic writing teaching and assessment. Apparently, representatives of both institutions appreciate the role of teachers in writing instruction and welcome teachers' feedback. At the same time, the respondents remain hesitant about the value of peer reviewing in academic writing. This corresponds to Ilkos' (2018) conclusions about specific attitudes to academic writing assessment in teacher-centered learning cultures. On the other hand, a survey carried out among students of English studies enrolled in the first-year writing course at University of Łódź (Majchrzak \& Salski, 2018) revealed positive attitudes to peer reviews, 
which does not quite coincide with our findings. This can be explained by the studies being conducted in non-identical educational settings.

Finally, academic integrity remains one of the most relevant topics for discussion. As our findings suggest, both countries experience similar problems, but address them in their own way, as indicative by the statistically significant difference in perceptions of plagiarism by students of LNU and UW found in our research. The higher confidence of UW students in dealing with plagiarism-related issues may imply that educational institutions of Poland take serious measures to fight plagiarism. Indeed Glendinning et al. (2015) contend that Polish educational institutions maintain a zero-tolerance policy towards any academic misconduct, implement sanctions and consequences to the violators of academic dishonesty, develop antiplagiarism software, etc. Ukrainian educational institutions, on the other hand, are now more focused on raising awareness among students in schools, colleges and universities (SAIUP). As academic integrity issues seem to be common for most Central and Eastern European nations (Chitez at al., 2018), educational institutions in these countries must persist in seeking effective measures to address academic dishonesty, Poland and Ukraine being no exception.

\section{LIMITATIONS OF THE STUDY}

There are two main limitations to this study - sample size, and acquiescence bias. The relatively small number of participants (60) in our survey cannot be representative of the population as a whole, and thus the results of the study cannot be generalized or transferred. Acquiescence bias can pose another threat to the validity of research results since people tend to agree with everything that sounds good especially if they are uncertain or hesitant (Dornyei, 2003).

\section{CONCLUSIONS}

In this small-scale study, we have addressed an array of questions connected with the development of academic literacy and academic writing practices at two institutions of higher education in Ukraine and Poland. Our findings lead us to a few inferences. Firstly, students of both universities apparently need more instruction in academic writing and better exposure to disciplinary genres of communication in both native and foreign languages. Secondly, the participants of the study showed low awareness of the role of language and communication in personal development as well as the educational potential of writing. Thirdly, the poor understanding of plagiarism issues demonstrated by students 
from Ukraine might indicate insufficient policies regarding academic integrity in that country. Due to the limitations of our study, the revealed tendencies cannot be regarded as generic. Nevertheless, we hope that this research will set the stage for further, more specific and focused follow-up studies of various aspects of teaching academic writing in Eastern European countries.

\section{ACKNOWLEDGMENTS}

A part of the survey presented in the article was carried out during one of the authors' (Mariya Kozolup) research stay at the University of Warsaw - Faculty of Education within the bilateral agreement between the University of Warsaw and Ivan Franko National University of Lviv.

\section{REFERENCES}

Allan, E. G., \& Driscoll, D. L. (2014). The three-fold benefit of reflective writing: Improving program assessment, student learning, and faculty professional development. Assessing Writing, 21, 37-55.

Anastasiadou, A., \& Aristotelous, P. (2015). Feedback revisited: The impact of peer commentary on students' attitudes and writing performance in the EFL classroom. An-Najah University Journal for Research (Humanities), 29(2), 369-402.

Bandura, A. (1997). Self-efficacy: The exercise of control. New York, NY: W. H. Freeman and Company.

Bazerman, C., Little, J., Bethel, L., Chavkin T., Fouquette D., \& Garufis, J. (2005). Reference guide to writing across the curriculum. West Lafayette, Indiana: Parlor Press.

Borglin, G. (2012). Promoting critical thinking and academic writing skills in nurse education. Nurse education today, 32(5), 611-613.

Britton, J. N. (1993). Language and learning (2nd ed.). Westport: Heinemann USA.

Chitez, M., Doroholschi, C., Kruse, O., Salski, Ł., \& Tucan, D. (Eds.). (2018). University writing in Central and Eastern Europe: Tradition, transition, and innovation. (MULT, volume 29). Cham, Switzerland: Springer.

Coffin, C., Curry, M. J., Goodman, S., Hewings, A., Lillis, T. M., \& Swann, J. (2003). Teaching academic writing: A toolkit for higher education. London \& New York: Routledge.

Cook-Sather, A., Bovill, C., \& Felten, P. (2014). Engaging students as partners in learning and teaching: A guide for faculty. San Francisco, CA: Jossey-Bass.

Curry, M., \& Hewings, A. (2003). Approaches to teaching writing. In C. Coffin, M. J. Curry, S. Goodman, A. Hewings, T. M. Lillis, \& J. Swann. Teaching academic writing: A toolkit for higher education (pp. 19-44). London \& New York: Routledge.

Dornyei, Z. (2003). Questionnaires in second language research: Construction, administration, and processing. Mahwah, NJ: Lawrence Erlbaum Associates. 
Duff, P. A. (2017). Language socialization, higher education, and work. In P. A. Duff \& S. May (Eds.), Language socialization. Encyclopedia of language and education (3rd ed., pp. 255-272). Cham, Switzerland: Springer

Flowerdew, J., \& Costley, T. (Eds.). (2016). Discipline-specific writing: Theory into practice. London: Routledge.

Glendinning, I., Jozwik, K., \& Michalowska-Dutkiewicz, A. (2015, April). Impact of policies for plagiarism in higher education across Europe: Plagiarism policies in Poland. Full report. Retrieved May 20, 2019, from http://plagiarism.cz/ippheae/files/D2-3-21\%20PL\%20IPPHEAE\%20CU\%20 Survey\%20Poland\%20Narrative\%20final.pdf

Gu, Q., \& Brooks, J. (2008). Beyond the accusation of plagiarism. System, 36(3), 337-352.

Hegbloom, M. R., Ramsey, L. R., Glen, N. J., Sabinin, P. D., Litvin, D. R., \& Veisz, E. (2017). Student voices on writing. Across the Disciplines, 14(2). https://wac.colostate.edu/docs/atd/articles/hegbloometal2017.pdf

Holaday, L. (1997). Writing students need coaches, not judges. In S. Tchudi (Ed.), Alternatives to grading student writing (pp. 35-45). Urbana, IL: National Council of Teachers of English.

Hyland, K. (2006). English for academic purposes: An advanced resource book. Abingdon: Routledge.

Ilkos, M. (2018). Using peer review with Greek EFL college students. Journal of Academic Writing, $8(2), 89-113$.

Klimova, B. F. (2013). Developing thinking skills in the course of academic writing. Procedia-Social and Behavioral Sciences, 93, 508-511.

Kobayashi, M., Zappa-Hollman, S., \& Duff, P. A. (2017). Academic discourse socialization. In P. A. Duff \& S. May (Eds.), Language socialization. Encyclopedia of language and education (3rd ed., pp. 239-254). Cham, Switzerland: Springer.

Kruse, O., Chitez, M., Rodriguez, B., \& Castello, M. (Eds.). (2016). Exploring European writing cultures: Country reports on genres, writing practices and languages used in European higher education. Winterthur: ZHAW Zurcher Hochschule fur Angewandte Wissenschaften.

Langer, J. A., \& Applebee, A. N. (1987). How writing shapes thinking: A study of teaching and learning. Urbana, IL: National Council of Teachers of English.

Lindahl, J., \& Grace, D. (2018). Students' and supervisors' knowledge and attitudes regarding plagiarism and referencing. Research Integrity and Peer Review, 3, Article 10.

MacArthur, C. A., Philippakos, Z. A., \& Graham, S. (2015). A multicomponent measure of writing motivation with basic college writers. Learning Disability Quarterly, 39(1), 31-43.

Mackey, A., \& Gass, S. (2005). Second language research: Methodology and design. Mahwah, NJ: Lawrence Erlbaum Associates.

Majchrzak, O., \& Salski, Ł. (2016). Poland. In O. Kruse, M. Chitez, B. Rodriguez, \& M. Castello. (Eds.), Exploring European writing cultures: Country reports on genres, writing practices and languages used in European higher education (pp. 149-162). Winterthur: ZHAW Zurcher Hochschule fur Angewandte Wissenschaften. 
Majchrzak, O., Salski, Ł. (2018). Peer review and journal writing in the eyes of first-year students of English studies: A writing course at the University of Łódź. In M. Chitez, C. Doroholschi, O. Kruse, Ł. Salski, D. Tucan (Eds.), University writing in Central and Eastern Europe: Tradition, transition, and innovation (MULT, volume 29, pp. 215-230). Cham, Switzerland: Springer.

McLeod, S. H. (1991). The affective domain and the writing process: Working definitions. Journal of Advanced Composition, 11(1), 95-105.

Ochs, E., \& Schieffelin, B. (2017). Language socialization: An historical overview. In P. A. Duff \& S. May (Eds.), Language socialization. Encyclopedia of language and education (3rd ed., pp. 3-16). Cham, Switzerland: Springer.

Pajares, F., \& Johnson, M. J. (1994). Confidence and competence in writing: The role of self-efficacy, outcome expectancy, and apprehension. Research in the Teaching of English, 28(3), 313-331.

Petric, B. (2002). Students' attitudes towards writing and the development of academic writing skills. The Writing Center Journal, 22(2), 9-27.

Rankins-Robertson, S., Cahill, L., Roen, D., \& Glau, G. R. (2010). Expanding definitions of academic writing: Family history writing in the basic writing classroom and beyond. Journal of Basic Writing, 29(1), 56-77.

SAIUP. (2019, Мау 20). Опитування 2016 і 2018 років в університетах-учасниках проекту SAIUP: порівняльний звіт. [2016 and 2018 surveys at universities-participants of SAIUP project: A comparative report] Analytical Center CEDOS, GfK Ukraine. Retrieved July 10, 2019, from https://saiup.org. ua/resursy/opytuvannya-2016-i-2018-rokiv-v-universytetah-uchasnykah-saiup-porivnyalnyj-zvit/

Tanyer, S. (2015). The role of writing and reading self-efficacy in first-year preservice EFL teachers' writing performance. Procedia - Social and Behavioral Sciences, 199, 38-43.

Vygotsky, L. S. [Выготский, Л. С.] (2005). The psychology of human development. [Психология развития человека.] Moscow: Smysl, Eksmo. [М.: Изд-во Смысл; Эксмо.]

Wood, D., \& Kurzel, F. (2008, November 20-21). Engaging students in reflective practice through a process of formative peer review and peer assessment [Conference presentation abstract]. ATN Assessment Conference 2008: Engaging Students in Assessment, Adelaide, South Australia. https://ojs.unisa. edu.au/index.php/atna/article/view/376

Yakhontova, T., Kaluzhna, H., Fitio, T., Mazin, D., \& Morenets, V. (2016). Ukraine. In O. Kruse, M. Chitez, B. Rodriguez, \& M. Castello. (Eds.), Exploring European writing cultures: Country reports on genres, writing practices and languages used in European higher education (pp. 263-280). Winterthur: ZHAW Zurcher Hochschule fur Angewandte Wissenschaften. 